\title{
The global status of chronic obstructive pulmonary disease
}

Chronic obstructive pulmonary disease (COPD) is a leading cause of mortality and morbidity worldwide (1). However, the status of COPD in each country varies. For example, the awareness of COPD in public differs between countries (2). Pulmonary function test (PFT) is a key component of COPD diagnosis. However, there is a huge difference in PFT performance rate worldwide (3). Also, inhalers are essential medication in COPD treatment. In spite of that, inhalers are not prescribed enough in some countries.

Smoking is a main cause of COPD. However, there are also several other causes for the development of COPD. The degree of biomass smoke exposure differs between countries. The low lung growth during childhood is also an important risk factor for COPD (4). However, the causes of low lung growth are various in each country. Moreover, the prevalence of childhood infection including tuberculosis also differs country by country.

The healthcare policy also can influence the epidemiology and management of COPD. The policy for smoking cessation can dramatically change the future incidence of COPD (5). The reimbursement criteria of inhalers in some countries such as Korea highly influences the prescription rate (6). Also, the government policy for air pollution affects the rate of acute exacerbation.

In spite of these worldwide differences, there have been few attempts to collect and review the worldwide aspect of COPD. In this focused issue, we did our best to invite world renown COPD experts from various regions and to review different aspects of COPD in the world. We do appreciate the efforts of all authors in this focused issue.

\section{Acknowledgments}

Funding: None.

\section{Footnote}

Provenance and Peer Review: This article was commissioned by the editorial office, fournal of Thoracic Disease for the series "current epidemiology and policies of COPD worldwide" published in fournal of Thoracic Disease. The article did not undergo external peer review.

Conflict of Interest: All authors have completed the ICMJE uniform disclosure form (available at https://dx.doi.org/10.21037/ jtd-21-1001). The series "current epidemiology and policies of COPD worldwide" was commissioned by the editorial office without any funding or sponsorship. Prof. CKR and Prof. KSJ serve as the unpaid Guest Editors of the series and serve as unpaid editorial board members of Fournal of Thoracic Disease. The authors have no other conflicts of interest to declare.

Ethical Statement: The author is accountable for all aspects of the work in ensuring that questions related to the accuracy or integrity of any part of the work are appropriately investigated and resolved.

Open Access Statement: This is an Open Access article distributed in accordance with the Creative Commons AttributionNonCommercial-NoDerivs 4.0 International License (CC BY-NC-ND 4.0), which permits the non-commercial replication and distribution of the article with the strict proviso that no changes or edits are made and the original work is properly cited (including links to both the formal publication through the relevant DOI and the license). See: https://creativecommons.org/licenses/by-nc$\mathrm{nd} / 4.0 /$.

\section{References}

1. GBD 2015 Chronic Respiratory Disease Collaborators. Global, regional, and national deaths, prevalence, disability-adjusted life 
years, and years lived with disability for chronic obstructive pulmonary disease and asthma, 1990-2015: a systematic analysis for the Global Burden of Disease Study 2015. Lancet Respir Med 2017;5:691-706.

2. Mun SY, Hwang YI, Kim JH, et al. Awareness of chronic obstructive pulmonary disease in current smokers: a nationwide survey. Korean J Intern Med 2015;30:191-7.

3. Kim KY, Yoo KH, Choi HS, et al. Nationwide quality assessment of treatment for chronic obstructive pulmonary disease. J Thorac Dis 2020;12:7174-81.

4. Lange P, Celli B, Agusti A, et al. Lung-Function Trajectories Leading to Chronic Obstructive Pulmonary Disease. N Engl J Med 2015;373:111-22.

5. Rhee CK, Chau NQ, Yunus F, et al. Management of COPD in Asia: A position statement of the Asian Pacific Society of Respirology. Respirology 2019;24:1018-25.

6. Lee J, Lee JH, Kim JA, et al. Trend of cost and utilization of COPD medication in Korea. Int J Chron Obstruct Pulmon Dis 2017;12:27-33.

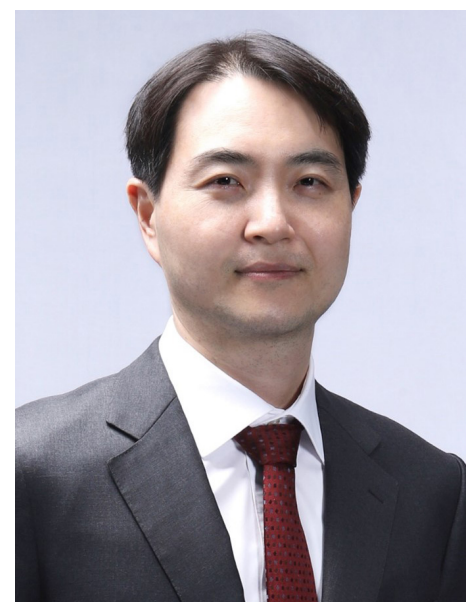

Chin Kook Rhee

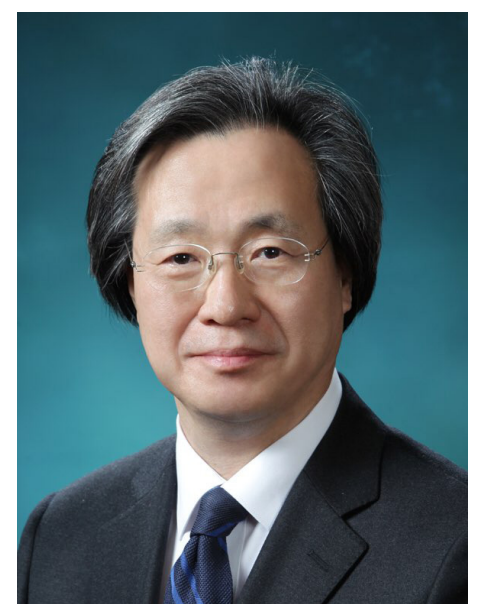

Ki-Suck Jung

Chin Kook Rhee

Division of Pulmonary and Critical Care Medicine, Department of Internal Medicine, Seoul St. Mary's Hospital, College of Medicine, The Catholic University of Korea, Seoul, South Korea.

(Email: chinkook77@gmail.com)

Ki-Suck Jung Department of Pulmonary, Allergy and Critical Care Medicine, Hallym University Sacred Heart Hospital, Anyang, South Korea.

(Email:pulmoks@ballym.ac.kr) Submitted Jun 05, 2021. Accepted for publication Jun 22, 2021. doi: $10.21037 /$ jtd-21-1001

View this article at: https://dx.doi.org/10.21037/jtd-21-1001

Cite this article as: Rhee CK, Jung KS. The global status of chronic obstructive pulmonary disease. J Thorac Dis 2021;13(6):3844-3845. doi: 10.21037/jtd-21-1001 